\title{
The power problematic: exploring the uncertain terrains of political ecology and the resilience framework
}

\author{
Micah L. Ingalls ${ }^{1,2}$ and Richard C. Stedman ${ }^{2}$
}

\begin{abstract}
Significant and growing concerns relating to global social and environmental conditions and processes have raised deep questions relating to the ability of traditional governance regimes to manage for the complexities of social-ecological systems. The resilience framework provides a more dynamic approach to system analysis and management, emphasizing nonlinearity, feedbacks, and multiscalar engagement along the social-ecological nexus. In recent years, however, a number of scholars and practitioners have noted various insufficiencies in the formulation of the resilience framework, including its lack of engagement with the dimensions of power within social-ecological systems, which blunt the analytical potential of resilience and run the risk of undermining resiliencebased management objectives. In this analysis, we engage with this power problematic by drawing on key insights from the scholarly tradition of political ecology, suggesting that a more appreciative, thoroughgoing engagement between resilience scholarship and political ecology may allow not only a deeper treatment of power within the resilience framework but also address several important critiques of political ecology itself. We explore the shared intellectual spaces of these traditions and suggest some ways in which a critical engagement between resilience and political ecology on the subject of power better informs our understanding of socio-political dynamics within complex systems. In closing, we train the critical light backward on political ecology to suggest that an appreciative engagement with the resilience framework may assist by reasserting a more serious treatment of ecology within political ecological analyses and support the formulation of more elegant, politically tractable counternarratives to address global environmental crises.
\end{abstract}

Key Words: political ecology; power; resilience; social-ecological systems

\section{INTRODUCTION}

Global environmental change, the persistence of endemic poverty, and warnings of heightened tensions surrounding resource scarcity draw attention to the potential failure of contemporary governance regimes to manage the complexities of the biospheric system. This in turn raises questions about the sufficiency of our dominant political and programmatic prescriptions to address these urgent threats (Escobar 1999). The failure of contemporary governance regimes to successfully manage for change has been attributed by some scholars and practitioners to the effects of equilibrium and steady-state models that underlie global natural resource governance regimes (Arrow et al. 1995, Berkes et al. 2000, Folke et al. 2002). As such, the case can be made for new governance paradigms founded on far-from-equilibrium approaches to complex systems' management. The resilience framework for the management of coupled social-ecological systems provides one such alternative paradigm, emphasizing nonlinearity, the importance of multiscalar feedback mechanisms, and a more dialectical understanding of social and ecological processes. Both as an analytical framework and as a mobilizing metaphor, resilience has been taken up within policies and programs across a number of sectors and geographic contexts (Bahadur et al. 2013) as what might arguably be considered the leading counternarrative for resource governance regimes across the world (Nelson et al. 2007, Walsh-Dilley et al. 2013).

Despite its prominence among some scholars and practitioners, the resilience framework has met with a number of critiques that suggest that current formulations of the framework are insufficient to engage with the complexities of social system dynamics (Davidson 2013) and ineffective at addressing core social science concepts (Duit et al. 2010). Critiques of the application of the resilience framework within socio-political contexts emphasize limitations based on its descriptive, analytic, and normative dimensions (Barrett and Constas 2014, Evans and Reid 2014). Key, and closely related, critiques relate to its tendency to assume or imply causal determinacy, its deprivileging of the role of individual and social agency (Adger et al. 2001, Davidson 2010), its insufficient engagement with the role of power in shaping social-ecological outcomes (Adger 2001, Davidson 2013, Cretney 2014), the conceptual framing of resilience not being propoor (Béné et al. 2012), and broader questions relating to the assumed consonance between social and ecological structures and functions (Welsh 2014). Taking these critiques seriously, we focus attention on a core objection relevant to each: that the fundamental assumptions of the resilience framework are naive about, or even perhaps unable to engage with, the workings of power (Walsh-Dilley et al. 2013). Power, as treated within the social science disciplines, has been defined and conceptualized in diverse ways. It is therefore useful here to define what we mean by power for our purposes. Paulson and others (2003:205) provide a definition of power as its operates across the nature-society nexus as "a social relation built on an asymmetrical distribution of resources and risks...[located in] the interactions among, and the processes that constitute, people, places and resources."

Several authors have recently begun to explore voices outside of the traditional canon of resilience scholarship that might aid in addressing this power problematic within the resilience framework. In these explorations, political ecology has emerged as a potential source of new insights and concepts that might enhance understanding of resilience within complex systems. Peterson (2000) presented one of the earliest explicit engagements, suggesting that resilience might benefit from political ecology's

${ }^{1}$ Poverty-Environment Initiative, United Nations Development Programme, ${ }^{2}$ Human Dimensions Research Unit, Department of Natural Resources, Cornell University 
engagement with power in social systems and, conversely, that concepts in resilience could be used to address political ecology's underdeveloped theorizing with regard to ecological system processes. Some subsequent scholarship has explicitly focused on such cross-fertilization, exploring how political ecology might help elucidate the functions of power in entrenched top-down governance structures in common property management (Armitage 2007), enable a stronger analytic focus on individuals, and allow for more politically sensitive understandings of social processes (Fabinyi et al. 2014). In another example, Turner (2014) explored the possibilities of a limited alliance between political ecology and resilience, suggesting that land-use ecology may serve as a possible point of constructive engagement. We suggest that despite these credible engagements we still lack a more thoroughgoing exploration of the terrains of these two areas of scholarship, and that such a deeper engagement is not only warranted but necessary. To this end, we map out some broad territories of these traditions, emphasizing both the shared spaces of each discourse and those areas of divergence. We then train a critical light on resilience, proposing a number of areas where political ecology brings new voices and insights to resilience's engagement with power, and in the final section, briefly train the critical light backward upon political ecology, suggesting some ways in which resilience thinking might usefully contribute.

\section{THE RESILIENCE FRAMEWORK}

The social-ecological resilience framework focuses attention on the function of complex dynamic systems, thresholds, nonlinear interactions between social and ecological system variables, interscalar relations, and how long periods of gradual, slow change interact with periods of rapid change (Holling 1973, Peterson 2000, Folke et al. 2002). Within such a conceptualization, large-scale, slow variables and disturbance regimes condition the parameters of the social-ecological system, while smaller, faster cycles and processes create disturbance, variability, and innovation (Berkes et al. 2000). These dynamic, interactive, and multiscalar processes produce a "stability landscape" (Gallopín 2006) consisting of a number of possible alternative configurations, each with its own stability domain, allowing for dynamism between stasis and change, and the basis for the system's adaptive capacity (Folke 2006). The mechanisms conferring resilience to a particular system, then, are those that enhance the ability of the system to negotiate change dynamics across this stability landscape, to reorganize following disturbance events, and to learn and adapt through time (Carpenter and Folke 2006). Some key attributes understood to condition resilience in complex social-ecological systems include diversity (allelic diversity as well as the diversity of species, functional groups, and institutions); heterogeneity (including, for example, landscape mosaics, habitats, and knowledge systems); the degree to which the system fosters innovation and learning; feedback responses between ecological signals and social responses; retention of system memory (such as through seed banks and nutrient sinks in the ecological subsystem or through formal and informal history, cultural norms, and indigenous knowledge in the social subsystem); self-organization rather than externally forced organization (Carpenter et al. 2001); and the nature and structure of cross-scale influences (Folke et al. 2002).

The resilience framework has broad, intuitive appeal and has contributed to our ability to conceptualize complex social- ecological systems and derive more nuanced management prescriptions that incorporate insights about the functioning of complex systems and help to address problems of global environmental change (Berkes and Ross 2013, Brown 2014). However, the emergence of the resilience framework from largely ecological roots has shaped the ways in which it allows us to perceive the social dimensions of complex systems (Miller et al. 2010), producing clear insights into some areas while obscuring insights into others, all with important implications for resiliencebased management (Armitage et al. 2012).

Central to this issue, as we have said, is the marginal role that power has played in the resilience framework, which has tended to regard questions of power and legitimacy as being largely outside of its purview (Cote and Nightingale 2012). Deprivileging the importance of power relations in social-ecological systems, or simply not getting them right, not only blunts the analytic potential of the resilience framework with regard to social and ecological system functions but also, in its practical application within real-world contexts, runs the risk of producing outcomes at variance with its intentions (Zimmerer 2006). In turn, this may discursively aid and abet inequitable governance structures and asymmetrical relations of power (Plummer and Armitage 2007, Cannon and Müller-Mahn 2010, Okereke and Dooley 2010). Questions of power also problematize the notion of resilience as an inherently desirable, normative goal for society (Engle 2011), recognizing that, for example, inequitable and oppressive governance regimes may certainly be resilient without being, by broad social consensus, desirable (Carr 2008, Olsson et al. 2014). Even the largely positive concepts of adaptation and transformation, which are highly suggestive of change away from undesirable systems, are by no means immune to co-option by powerful actors who also use such mechanisms to entrench and protect their interests or social legitimacy when these become untenable under existing social or ecological conditions (Davidson 2010, Brown 2014, Béné et al. 2014).

Cote and Nightingale (2012:484) observe that "resilience is a power-laden framework that creates certain windows of visibility on the processes of change, while obscuring others." Such selectivity with regard to the relations of power within naturesociety interactions may be usefully thought of as conjoining "sins of commission," the potentially dangerous logical fallacies and incoherencies underpinning the way resilience treats power and apprehends its function in social-ecological systems, with "sins of omission," when the resilience framework is simply silent with regard to the role that power dynamics play in structuring these functions. Although disaggregating along this distinction is a useful way to frame our critique of the treatment of power within the resilience framework, this distinction in some sense breaks down when we recognize that both silences with regard to power and misconceptions of it are highly problematic.

\section{TRADE-OFFS IN RESILIENCE}

The functions of power within the governance of social-ecological systems become perhaps most critical when trade-offs in the broadest sense are conceptualized, framed, and negotiated (Wolf and Allen 1995, Miller et al. 2010). It is axiomatic that there will always be winners and losers from the processes and outcomes of environmental governance in general (Adger 2003) and during periods of system change in particular, when the interests of some 
actors are privileged over the interests of others (Adger 2001), raising social and normative questions of legitimacy (Brown et al. 2013) and technical questions regarding the differential costs and benefits accruing to social versus ecological system components. There exists a great deal of uncertainty regarding the content and magnitude of these trade-offs (Agrawal and Redford 2006) and the emergent impacts exacerbated by the irregularities of global environmental change and the diverse ways in which the adjudication of these trade-offs is negotiated through relations of power (Hirsch et al. 2011). Although dynamics of power and questions of deliberative and distributive justice already plague current social problems arising from the relative scarcity manifest within current resource systems, global environmental change threatens to exacerbate these problems by presenting the real possibility of global scarcity in absolute terms (Davidson 2013) because systems are unable to provide for the needs of all (Kasperson et al. 1996), prompting the fundamental question "resilience for whom?" (Lebel et al. 2006). In light of all these issues, it is necessary that resilience science takes seriously the operations of power along the social-ecological nexus of these trade-offs by actively interrogating the ways in which these and other processes along the social-ecological nexus are filled with power relations.

A reformulation of the resilience framework that more adequately incorporates a critical approach to understanding the origins, exercise, and effects of power will allow it to more effectively engage with the increasingly complex and interrelated systems, and effectively adjudicate the diverse and contested claims of various stakeholders at multiple spatial and temporal scales (Brown et al. 2013), who may hold different perspectives on what constitutes the appropriate objects and goals of resilience (Coulthard 2012). Political ecology provides us with some of the tools that may support such a reformulation.

\section{POLITICAL ECOLOGY}

Given the complexity of the various traditions and scholarly contributions that comprise political ecology, arriving at a coherent and comprehensive definition is a somewhat synthetic task. The earliest, and perhaps most overtly Marxist, definition offered by Blaikie and Brookfield (1987:17) explains that "the phrase "political ecology' combines the concerns of ecology and a broadly defined political economy...[and] the constantly shifting dialectic between society and land-based resources, and also within classes and groups within society itself. We also derive from political economy a concern with the role of the state. The state commonly tends to lend its power to dominant groups and classes." Subsequent and potentially useful contributions to this early definition of the field have emphasized variously its material dimensions, relating the struggle over resources and the constitution of a politicized environment in the Global South (e.g., Bryant 1998) and its emphasis on how power asymmetries are expressed in and supported by discursive struggles over meanings in history and biology (e.g., Escobar 1999). A more recent definition emphasizes both the material and discursive tendencies of the field: "[Political ecology is] concerned with tracing the genealogy of narratives concerning the environment, with identifying the power relationships supported by such narratives, and with asserting the consequences of hegemony over, and within, these narratives for economic and social development, and particularly for constraining possibilities for self-determination" (Stott and
Sullivan 2000:2). In short, political ecology is fundamentally about the role of power along the social-ecological nexus.

Despite the broad extension of the term and its introduction to a diverse set of subdisciplines and related disciplines, there remains a set of core concerns common across much of the political ecology discourse, centering on the dialectical relationship between nature and society (Watts 2009). Core assumptions include (1) that there is an unequal distribution of both the costs and benefits associated with environmental change, which reproduces the structural power asymmetries that were the cause of these differential distributions (Okereke 2006); and relatedly, (2) environmental degradation is both the cause and result of social marginalization, wherein asymmetrical relations of power exacerbate degradation through pressures of production on the natural environments of the poor and powerless (Paulson et al. 2003).

Despite important differences, the historical developments of political ecology and the resilience framework provide a legacy of some shared concepts and analytical approaches. Articulating the dialogic territory between political ecology and resilience requires that we map out the intellectual spaces of each, relating to the common focal topics of interest, research purposes, and the ways in which each engage with complex systems. Both political ecology and social-ecological resilience focus their attention explicitly on the nature-society nexus as a core interest (Zimmerer 2007), and although each tradition articulates the relational processes operative along this nexus in different ways, the conceptual similarities are great enough to allow for a degree of mutual intelligibility. Social-ecological resilience conceptualizes social and ecological elements and processes as constantly interpenetrating and articulates this relationship in the language of systems thinking; political ecology regards social and ecological relations similarly, as dialectical and mutually constitutive. Paulson et al. (2003:210), for example, assert that the core of political ecology is the commitment to "account for the dialectical processes through which humans appropriate, contest and manipulate the world around them, and to understand and act on the ecological and social impacts of those processes"; this objective is very similar to that of social-ecological resilience. With regard to systems thinking, political ecology and social-ecological resilience both reject Clements's (1936) model of ecological succession (Sayre 2008); understand human and ecological systems as complex and dynamic (vs. linear, or reducible); tend to hold nonequilibrium understandings of complex systems function (Walker 2005), focusing their attention on drivers of system disturbance rather than forces of stasis; and engage with systems in explicitly multiscalar ways (Ferguson and Derman 2005).

Mapping out these shared conceptual, analytical, and methodological spaces is as important for demonstrating their intellectual commonalities as for casting in relief (if you will) their key points of divergence. First, where social-ecological resilience has tended to regard questions of power as largely outside of its purview, political ecology situates such questions at the core of its analysis. Second, and related, where social-ecological resilience focuses on the system as the basic unit of analysis and thus casts disturbances as generally exogenous to the system of interest, 
political ecology also attends to the conditioning effects of endogenous system dynamics, such as the power asymmetries that produce vulnerability through the "everyday marginalization" of poorly positioned actors (Gaillard 2010). The intellectual borderlands shared by these traditions facilitate interdisciplinary dialogue, i.e., allow them to talk to each other, while the key points of divergence provide impetus for critical engagement, i.e., give them something important to talk about. At present, however, underdeveloped theorizing with regard to questions of power in the resilience framework has contributed to mutual misunderstanding, i.e., talking past each other, and truncated coanalysis. What is critical for our purposes here is that engaging with questions of power in complex systems is not merely a case of introducing yet another variable into the already complex analyses provided by the resilience framework. Rather, a meaningful engagement with the claims and insights of political ecology not only allows for the possibility of a more nuanced and informative conceptualization of system process, but also may in fact change the picture entirely (Massey 1999) by radically recasting the analyses and prescriptions of resilience thinking's comparatively unproblematized narratives (Walsh-Dilley et al. 2013).

A dialogic lynchpin between resilience and political ecology is the issue of power. We will explore some ways in which the construction and function of power, as articulated through political ecology, problematize some of the core notions of the resilience framework and how these problematic elements may be addressed. Although we certainly do not present an exhaustive treatment of resilience through the political ecology lens, we illustrate some of the kind of insights that political ecology might bring to resilience thinking.

\section{POWER, KNOWLEDGE, AND DISCOURSE}

The governance of social-ecological systems is contingent upon the processes by which knowledge is generated, codified, and brought to bear on the problems and solutions of management. These social processes underlie our ability to understand system dynamics, locate and describe the origin and nature of disturbances, and structure and implement appropriate management interventions. In the resilience framework, knowledge tends to be codified in scientific assessments, referenced in determining appropriate (and usually ecologically based) scales of analysis and actions, and brought to bear in adjudicating the appropriate mechanisms of adaptive management. Resilience thinkers have noted analytical biases introduced by the uneven distribution of knowledge, such as the irregular availability of data sets (Cumming 2011), and have noted the possibility of non-Western epistemologies (Berkes et al. 2000). However, comparatively little critical attention has been paid to why these data biases exist or what powers are implicated in the differential distribution and credibility of divergent knowledges. For political ecology, by contrast, these questions are crucial to understanding the relationship between knowledge and power, which are understood to almost universally overlap (Flynn 2007) and to play a central role in structuring the truth regimes that undergird governance of society-nature relations and shape social and ecological outcomes (Bryant 1998). Central to this analytical focus is the notion that environmental knowledge is not only an object out there to be grasped but also a social construction. Said differently, environmental knowledge as apprehended by political ecology is not merely a content or a set of data points, but an emergent property of the formal and informal, discursive, relational, and dialectical interactions of society and nature (Wolf 2011) conditioned by the asymmetrical relations of power that are transmitted and reproduced by it (Foucault 2007). That different actors in society possess differing degrees of knowledge and hold various theories or conceptualizations of social or ecological system processes is hardly contestable and well within the realm of resilience thinking. However, the key questions "Who is allowed to the table in negotiating these contestations?" and "Who is allowed to utter the definitive statement in a controversy?" (Flynn 2007:61) are not adequately engaged; in short, "Whose reality counts?" (Chambers 1997). Divergent knowledge regimes arise not only from differential access to knowledge but also from the multiplicity of rationalities (the Foucaltian "polyhedron of intelligibility") emergent from the perspectival and situated nature of knowing (Escobar 1998). Exploring this relationship between knowledge/power, diverse rationalities, and situated knowledges - interrogating their points of coincidence and divergence-is much more than an exercise in epistemology; it becomes critical when it comes to deciding the right way of doing things in the projects of environmental governance (Cote and Nightingale 2012). Taking these insights seriously within resilience-based scholarship would involve active consideration of the kinds of knowledge that are, or could be, brought to bear in the analysis of social-ecological systems and the dimensions of power through which these knowledges are constructed and (de)legitimized. It also involves interrogating how the invocation of various knowledges within analysis and management decisions shapes the distribution of costs and benefits within the system. Power-filled constructs of knowledge materialize in the discursive structures that frame analyses and their associated prescriptions for strengthening resilience in social-ecological systems. Unpacking these discourses entails a careful analysis of their content, the relations of power that produce this content, and their material outcomes within realworld systems. This process, i.e., discourse analysis, is a useful contribution from the toolbox of political ecology that can enable resilience thinking to interrogate how power functions to structure environmental knowledge within social-ecological systems and to what effect (Arts and Buizer 2009).

Exploration of the "unique discursive physiognomy" (Foucault 2007) of environmental discourses has been central to political ecology since its origin in the work of Piers Blaikie (1985). Since that time, exploration of the role of language in politics (Hajer and Versteeg 2005) has, for example, produced compelling insights into the ways in which environmental narratives have functioned as framing devices to legitimate the interventions of state actors and international agencies and thus the expansion of governmentalizing projects of the state.

A specific example might be helpful here. Shifting cultivation is a livelihood system that both forms the basis of local livelihoods for upland communities and poses a risk to, among others, timber and forest carbon values of interest to the state. Ingalls and Dwyer (2015) argued that although shifting cultivation within a protected area in Lao PDR formed the basis of complex social-ecological landscapes and a key adaptive strategy of local communities, it nevertheless has become the primary target of Reduced Emissions from Deforestation and Degradation programming. By invoking 
a long-standing, and scientifically ambiguous, environmental narrative that discursively casts shifting cultivation as backward and environmentally destructive, state authorities were able to legitimize interventions to conserve one specific environmental value, i.e., standing forest biomass, at the expense of broader social-ecological functions. Locating the cause of environmental degradation in the inadequate practices and knowledge of the poor (Basset and Zueli 2003), creating simplifying narratives of the social and ecological worlds of their subjects that ignore local agency, and eliding complex social-ecological realities (Barney 2009) allow these narratives to legitimize the reterritorialization of local resources (Brogden and Greenberg 2005). This is accomplished via enclosure of the commons by the creation of protected areas (separating "peopled spaces" from "nature spaces," Baird 2009) and other forms of appropriation (Peluso and Lund 2011).

Although the exercise of raw or elemental power perpetrated by, e.g., governments, militaries, or corporations may bring about the accumulation of resources through dispossession, such actions are short-lived when they are not able to construct plausible narratives that legitimize their actions. Another example, taken from the same region, may be helpful here as well to illustrate that even overt seizures of territory may nevertheless be couched in such legitimizing discursive framings. The creation of protected areas and other political forests in former Indochina took place within broader socio-political processes of state formation, insurgency, and border conflicts during the latter half of the 20th century. Dwyer and others (2015) show how in Lao PDR, long after these security issues were resolved but in a time of rising demand for high-value timber species and increased pressures from cross-border logging, historical legacies of border insecurity and counterinsurgency have been invoked by contemporary military actors to appropriate forest resources within protected areas and exclude local communities. By casting transboundary logging operations as not only environmental threats but also risks to national security and the political forest estate, military actors were able to politically legitimize these appropriations, despite their overt economic intent.

What is critical here is that discourses are words, but they are not merely words. They are political constructs of power that legitimize certain policy orthodoxies and materialize in laws and programmatic prescriptions with practical and material outcomes (Arts and Buizer 2009) along the society-nature nexus. In so doing, they play a key role in formulating and justifying policy prescriptions that condition the resilience of social-ecological systems. By failing to carefully interrogate constructed environmental discourses, the resilience framework runs a substantial risk of ignoring or, worse, supporting the accumulation, dispossession, and appropriations legitimized by them. More care could be taken within resilience-based analyses to interrogate the ways in which various actors define environmental degradation and ascribe the causes of these processes, asking who stands to gain or lose from particular environmental narratives and from the proposed corrective interventions.

\section{POWER AND THE POLITICS OF SCALE}

Another area where political ecology may usefully contribute relates to the treatment of scale, an issue that is core to social- ecological analysis (Cumming et al. 2006). Resilience thinking has made the important points that environmental and social problems often occur because of a failure to address issues of governance at appropriate scales and that the spatial and temporal fluidity of heterogeneous social-ecological system dynamics requires equally flexible institutional arrangements (Carpenter and Brock 2004). Further, resilience recognizes that engagement at one scale cannot be done without paying proper attention to cross-scale dynamics, including the role of subsidies (e.g., through nutrient and species flows, or through the financial or human capital subsidization between scales; see Carpenter et al. 2001 for examples of the latter) that condition the resilience of systems (Adger et al. 2006) and, often, mask the impacts of system degradation (Cumming et al. 2006).

Taking these observations to a higher scalar level, resilience scholarship has observed that in a globalized world where actions are increasingly uncoupled from their impacts in space and time, and local decisions have intergenerational consequences, governance must transcend geopolitical boundaries to engage with the multiscalar nature of social and ecological change (Peterson 2000, Jax and Rozzi 2004). Although the appropriate scale of governance in social-ecological systems is in some sense global, there is an important sense in which analysis of the realworld implications of multiscalar governance regimes is most appropriately done at the local level, where these processes produce their on-the-ground impacts (Adger 2001).

Resilience scholarship's recognition of the importance of appropriate scaling, the need for dynamic, spatially and temporally flexible institutions to manage the fluidity of complex social-ecological system functions, and the conditioning effects of cross-scale dynamics are all important contributions to the governance of complex systems, although they are somewhat underdeveloped within political ecology. Still lacking are thoughtful analyses of how scalar decisions are made within resilience studies and how these decisions play a role in shaping the outcomes of these analyses, all with implications for management. Rather than being a spatial object, scale is an analytic category that refers specifically to the "the spatial, temporal, quantitative and analytical dimensions used to measure and study any phenomenon" (Cash et al. 2006:9) or the spatial patterning of human-environment interactions (Zimmerer 2006). Said differently, scaling is "the act of defining the spatiotemporal level or levels of interest when attempting problem solving" (Wolf and Allen 1995:5).

Armitage and Johnson's (2006) analysis of resilience and globalization in two Asian coastal systems in the state of Gujarat, India, and the province of Central Sulawesi, Indonesia, is illustrative. In both coastal systems, rapid economic transformations enabled by global market conditions have brought about substantial and potentially catastrophic changes in social-ecological conditions. The potential collapse of these local coastal systems points in one direction to a loss of resilience at the local level but also in the other direction to a robust global economic system that changes rapidly to exploit local resources, leading the authors to observe that resilience assessment depends largely on the focal scale of interest. The question of whether the system of interest is resilient is contingent on whether the local or global system is the focal scale of interest. This is significant 
because resilience-based assessments either implicitly or explicitly form the basis of policy prescriptions. The application of the resilience framework at one scale of analysis may suggest that certain policies or programs might strengthen resilience, whereas analysis at a higher level (such as in this case) may indicate precisely the opposite. Scanning across resilience-informed assessments suggests that this may be a persistent issue for the resilience framework. Not only do resilience-based assessments tend to focus on local systems, potentially missing key globalscalar processes and outcomes, but they also seldom delve below them (Fabinyi et al. 2014), likely ignoring the ways in which the resilience of even local systems may be enabled through the loss of resilience among lower levels of analysis. Taking this insight from political ecology seriously entails that resilience assessments look more closely at how scalar decisions are made during analysis, what power processes are operative within these decisions, and how power may function across these scales to build or erode resilience. Analyzing the politics of scale, i.e., the power dynamics expressed in the selection of focal scale, scalar bounding, and the impacts of these, requires that we recognize that scales of interest are neither given nor politically neutral (Castree 2004). They are social constructions that embody and express power relationships (Basset and Zueli 2003), are historically contingent, and are contestable. Although the constructed nature of scale within social systems may be relatively more obvious, it is important to recognize the less obvious point that even ecological scales are socially produced. The analyst must (de)select from among nearly limitless ecological variables, a subjective selection that then determines the scalar frame of subsequent analysis. These selections are significant because system dynamics are inherently sensitive to changes in analytical context determined by focal scale (Wolf and Allen 1995). System process patterns that emerge at a particular focal scale may disappear, or even be contradicted, as we move from one focal scale to another, all with important implications for analysis and prescription. In the resilience framework, these scalar effects and their intersection with power become apparent, for instance, when the spaces of marginalized people become invisible at the focal scales of decision makers (Adger 2003).

Sayre (2005) observed that the selection of a focal scale has two moments: the epistemological (the point at which the scalar selection is made) and the ontological (the point from which the selected scale is treated as a given, or an objective feature of the focal system). Too often, the resilience framework passes from one moment to the other without mention. This elision may be a function of resilience's rather deeper ecological than social roots: a history that produces one further weakness in resilience's treatment of scale. The observation that scalar mismatch is "the most archetypical problem" (Cash et al. 2006) in the governance of social-ecological systems is a diagnosis for which the prescription is appropriately scaled governance systems, meaning the scaling of social governance regimes to accord with the "natural" scale of ecosystem processes. In this way, resilience prescribes, in an all-too-normative fashion, that it is wrong to structure institutions of governance along nonecological organizing principles (Cumming et al. 2006). Privileging ecological scale, and not recognizing that this scale is also a social construction, along Western scientific categories may be problematic for a variety of reasons, not least of which in that it assumes that nonecologically aligned jurisdictional or administrative scales are inappropriate for determining scales of environmental governance, although these may have possibly very legitimate rationalities rooted in their own antecedent social histories (Adger 2003). They may also ignore other spatial categories that may be far more salient to local actors, such as connectivities along ethnic or tribal lines (Escobar 1998). Resilience may benefit from taking more seriously alternative, possibly nonecological, social and cultural processes of scalar signification and from recognizing that scalar selection in the real world is always multivariate, adjudicated according to social, political, and ethnic criteria as well as ecological ones, all of which are populated with the functions of typically asymmetrical power relationships. We suggest that resilience-based analyses may be enhanced by interrogating the subtext of scalar selections, asking the following questions: Who decides what the appropriate scale is, and of what? Who wins and who loses in these decisions? What are the political implications of social scaling processes? Although these questions have been lightly touched on within the resilience literature, which notes at least in a cursory way that subjectivity is involved in parameterizing and bounding complex systems (e.g., Cumming et al. 2005) and that scales are perceived and valued differently by different actors (Cash et al. 2006), these passing references are indicative of resilience thinking's tendency to deprivilege considerations of power that otherwise figure prominently in the political ecology tradition (Armitage 2007).

The political ramifications of scalar decisions are central to the resilience of social-ecological systems and have very material outcomes, determining which processes are visible or invisible at any given scale (and by implication, what drivers of change are important) and playing a formative role in structuring the differential distribution of costs and benefits within and across scales that vary with the scalar selection (Sayre 2005, Adger et al. 2006). Thus, when resilience analysts and practitioners invoke spatial dimensions that unwittingly draw on hidden or unproblematized power networks, they may produce outcomes that diverge from their intended impacts (Zimmerer 2006).

\section{TRAINING THE CRITICAL LIGHT BACKWARD: RESILIENCE ON POLITICAL ECOLOGY}

Recent scholarship addressing the shared, contested, and divergent spaces of resilience and political ecology has tended to focus on the inadequacies of resilience in light of critical theory. A more productive and informed dialogue between the two requires a readjustment of this unidirectionality. Therefore, we train the critical light backward, asking what insights resilience brings to political ecology. We very briefly identify some weaknesses of political ecology and suggest some ways in which social-ecological resilience may usefully contribute.

First, in its analysis of the nature-society nexus, political ecology has been criticized for its a priori assumption that factors related to the political economy not only are influential in shaping socialecological outcomes but necessarily dominate them (Vayda and Walters 1999), privileging politics at the expense of ecology (Paulson et al. 2005) and becoming "politics without ecology" (Walker 2005). To the degree that is true, it is not a trivial omission. Understanding the full ramifications of socio-political power asymmetries for the lived experiences of the poor and marginalized may not be possible without a deeper and more nuanced 
understanding of relevant ecological processes. Parsing the myriad causal processes within ecological systems, which is necessary for adequately understanding the implications of society-nature interactive effects, is a notoriously complicated endeavor. General assertions regarding the causes and consequences of environmental change and degradation in the absence of careful and theoretically informed analysis may not be sufficient or, worse, may lead to significant misattribution of causes and effects. Second, political ecology has often been criticized for being long on critique but short on concrete, actionable recommendations and has thus enjoyed rather broader acceptance within academia than outside of it. Insofar as political ecology seeks to constructively address disempowering policy narratives, the distortions of globalized market mechanisms, neoliberalist politico-corporate hegemony, and other structures of marginalization, it is necessary to move from critique to prescription. In some sense, political ecology has neglected its historical precedent in providing practical prescriptions emergent from its critical and potentially liberating counternarratives (Gezon and Paulson 2005) by willfully avoiding the "messy, constrained world [outside of academia]" (Piers Blaikie, personal communication, as cited in Walker 2006). To whatever degree political ecology has been unable or unwilling to gain traction among global policy processes, institutions, and programming, it will be unable to fulfill this intention.

An appreciative scholarly encounter with resilience may provide some direction for addressing these shortcomings. First, although political ecology may be lacking in nuance and analytic rigor with regard to its treatment of ecological system dynamics, resilience focuses attention directly on these elements and provides numerous tools not only for understanding the complexities of ecological processes but also for linking these back to social dynamics. A deeper understanding of multiscalar ecological processes, thresholds, nonlinearity, and surprise, such as is elucidated within resilience-based approaches, will strengthen political ecology's ability to more accurately and specifically interrogate the ecological implications of the political economy for the disempowered. Second, although political ecology has played an important role in critiquing dominant narratives of global environmental governance, resilience scholarship has been rather more successful in producing the compelling environmental counternarratives to these approaches (such as historical equilibrium-based maximization assumptions) that have gained traction within the institutions and policy platforms of global decision making. Constructive and forward looking, resilience-based scholarship has positively, if sometimes naively, framed approaches of possibility, prescription, and action for addressing the pressing issues of global environmental change. This may, and we think should, prompt some useful reflection within political ecology. Critical theorists must be willing to explore political ecology's own sins of omission and commission, and break out of the "verdant but largely peripheral pastures of academia" (Walker 2006:392) and be willing to engage in the hurly-burly of the messy world of policy prescription and programmatic action.

\section{CONCLUSION}

The power problematic is, and will likely remain, a key issue for resilience science. For some, this signifies a fundamental and intractable flaw in resilience science's basic premise and core assumptions. We remain unconvinced. In our estimation, resilience scholarship's sins of omission loom rather larger than its sins of commission, although both are tractable. Notwithstanding its insufficient exploration of these and other social dynamics, resilience remains a potent mobilizing metaphor (Pain and Levine 2012) and a useful organizing concept (Brown 2014), and will probably continue to play a highly visible role in global discourses on environmental and social governance, informing policy and practice. A particular strength of resilience thinking rests in its ability to reframe existing theoretical constructs and analytic approaches, but this needs to be taken seriously and carried out with due diligence. Resilience scientists stand to gain by more adequately educating themselves on the insights of political ecology and directly engaging with the power problematic; in so doing, they may produce a much deeper and more radical critique of society-environment relations (Hornborg 2013). In particular, resilience scholarship may be enhanced by the politicization of its givens. Paying critical attention to the sorts of knowledge it privileges, the (re)production of these knowledges, and their systematic invocation through particular discourses, resilience scholarship may result in deeper insights into the power dynamics embedded in such social and political processes, and the ways these may intersect with resilience at multiple levels. Similarly, by paying critical attention to its scales of analysis, how and by whom scalar decisions are taken and to what effect, resilience thinking may be better positioned to understand how these processes of scalar signification elucidate or elide particular social processes and divergent interests.

Political ecology may also benefit from a more rigorous analytic framing of ecosystem processes and their intersection with social dynamics as a complement to its historically disproportionate focus on the political economy. Bringing together resilience's forward-looking and prescriptive approaches with political ecology's overt focus on power asymmetries may be a boon for both, providing tractable and informed approaches to addressing pressing issues along the society-nature interface.

We have sought to point to a number of ways through which the power problematic may be more adequately addressed within social-ecological systems. More remains to be done both in fleshing out the theoretical footing of a political ecology of resilience and in operationalizing these approaches within particular social-ecological contexts.

Responses to this article can be read online at: http://www.ecologyandsociety.org/issues/responses. $\mathrm{php} / 8124$

\section{Acknowledgments:}

We wish to thank Steven Wolf at Cornell University for his helpful comments on an earlier draft of this manuscript, as well as three anonymous reviewers for their insightful critiques. We also wish to acknowledge and express our appreciation to our colleagues at Cornell University, the United Nations Development Programme, the World Wide Fund for Nature, the Center for International Forestry Research, and the Stockholm Resilience Center- too numerous to mention by name - for the discussions and interactions which helped shape these efforts. 


\section{LITERATURE CITED}

Adger, W. N. 2001. Scales of governance and environmental justice for adaptation and mitigation of climate change. Journal of International Development 13(7):921-931. http://dx.doi. org/10.1002/jid.833

Adger, W. N. 2003. Social capital, collective action, and adaptation to climate change. Economic Geography 79 (4):387-404. http://dx.doi.org/10.1111/j.1944-8287.2003.tb00220. $\underline{\mathrm{X}}$

Adger, W. N., T. A. Benjaminsen, K. Brown, and H. Svarstad. 2001. Advancing a political ecology of global environmental discourses. Development and Change 32(4):681-715. http://dx.doi. org/10.1111/1467-7660.00222

Adger, W. N., K. Brown, and E. L. Tompkins. 2006. The political economy of cross-scale networks in resource co-management. Ecology and Society 10(2):9. [online] URL: http://www. ecologyandsociety.org/vol10/iss2/art9/

Agrawal, A., and K. Redford. 2006. Poverty, development, and biodiversity conservation: hooting in the dark? Working paper No. 26. Wildlife Conservation Society, Bronx, New York, USA.

Armitage, D. 2007. Governance and the commons in a multi-level world. International Journal of the Commons 2(1):7-32. http://dx. doi.org/10.18352/ijc. 28

Armitage, D., C. Béné, A. T. Charles, D. Johnson, and E. H. Allison. 2012. The interplay of well-being and resilience in applying a social-ecological perspective. Ecology and Society 17 (4):15. http://dx.doi.org/10.5751/ES-04940-170415

Armitage, D. R., and D. Johnson. 2006. Can resilience be reconciled with globalization and the increasingly complex conditions of resource degradation in Asian coastal regions? Ecology and Society 11(1):2. [online] URL: http://www. ecologyandsociety.org/vol11/iss1/art2/

Arrow, K., B. Bolin, R. Costanza, P. Dasgupta, C. Folke, C. S. Holling, B.-O. Jansson, S. Levin, K.-G. Mäler, C. Perrings, and D. Pimentel. 1995. Economic growth, carrying capacity, and the environment. Ecological Economics 15(2):91-95. http://dx.doi. org/10.1016/0921-8009(95)00059-3

Arts, B., and M. Buizer. 2009. Forests, discourses, institutions: a discursive-institutional analysis of global forest governance. Forest Policy and Economics 11(5-6):340-347. http://dx.doi. org/10.1016/i.forpol.2008.10.004

Bahadur, A. V., M. Ibrahim, and T. Tanner. 2013. Characterising resilience: unpacking the concept for tackling climate change and development. Climate and Development 5(1):55-65. http://dx.doi. org/10.1080/17565529.2012.762334

Baird, I. G. 2009. Spatial (re)organization and places of the Brao in southern Laos and northeastern Cambodia. Singapore Journal of Tropical Geography 30:298-311. http://dx.doi.org/10.1111/ j.1467-9493.2009.00378.x

Barney, K. 2009. Laos and the making of the 'relational' resource frontier. Geographical Journal 175(2):146-159. http://dx.doi. org/10.1111/j.1475-4959.2009.00323.x
Barrett, C. B., and M. A. Constas. 2014. Toward a theory of resilience for international development applications. Proceedings of the National Academy of Science of the United States of America 111(40):14625-14630. http://dx.doi.org/10.1073/pnas.1320880111

Basset, T. J., and K. B. Zueli. 2003. The Ivorian savannah: global narratives and local knowledge of environment change. Pages 115-136 in K. S. Zimmerer and T. J. Bassett, editors. Political ecology: an integrative approach to geography and environmentdevelopment studies. Guilford, New York, New York, USA.

Béné, C., R. G. Wood, A. Newsham, and M. Davies. 2012. Resilience: new utopia or new tyranny? Reflection about the potentials and limits of the concept of resilience in relation to vulnerability reduction programmes. IDS Working Paper 405. Institute of Development Studies, Brighton, UK. http://dx.doi. org/10.1111/j.2040-0209.2012.00405.x

Béné, C., A. Newsham, M. Davies, M. Ulrichs, and R. GodfreyWood. 2014. Resilience, poverty and development. Journal of International Development 26(5):598-623. http://dx.doi.org/10.1002/ jid.2992

Berkes, F., C. Folke, and J. Colding, editors. 2000. Linking social and ecological systems: management practices and social mechanisms for building resilience. Cambridge University Press, Cambridge, UK.

Berkes, F., and H. Ross. 2013. Community resilience: towards an integrated approach. Society \& Natural Resources 26(1):5-20. http://dx.doi.org/10.1080/08941920.2012.736605

Blaikie, P. 1985. The political economy of soil erosion in developing countries. Longman, Essex, UK.

Blaikie, P., and H. Brookfield. 1987. Land degradation and society. Methuen, London, UK.

Brogden, M. J., and J. B. Greenberg. 2005. The fight for the west: a political ecology of land-use conflicts in Arizona. Pages 41-60 in S. Paulson and L. L. Gezon, editors. Political ecology across spaces, scales, and social groups. Rutgers University Press, New Brunswick, New Jersey, USA.

Brown, K. 2014. Global environmental change I. A social turn for resilience? Progress in Human Geography 38:107-117.

Brown, K., S. O’Neill, and C. Fabricius. 2013. Social science understandings of transformation. Pages 100-106 in World social science report 2013: changing global environments. OCDE Publishing and UNESCO Publishing, Paris, France. http://dx. doi.org/10.1787/9789264203419-13-en

Bryant, R. L. 1998. Power, knowledge and political ecology in the third world: a review. Progress in Physical Geography 22(1):79-94.

Cannon, T., and D. Müller-Mahn. 2010. Vulnerability, resilience and development discourses in the context of climate change. Natural Hazards 55(3):621-635. http://dx.doi.org/10.1007/ s11069-010-9499-4

Carpenter, S. R., and W. A. Brock. 2004. Spatial complexity, resilience, and policy diversity: fishing on lake-rich landscapes. Ecology and Society 9(1):8. [online] URL: http://www. ecologyandsociety.org/vo19/iss1/art8/ 
Carpenter, S. R., and C. Folke. 2006. Ecology for transformation. Trends in Ecology \& Evolution 21(6):309-315. http://dx.doi. org/10.1016/j.tree.2006.02.007

Carpenter, S., B. Walker, J. M. Anderies, and N. Abel. 2001. From metaphor to measurement: resilience of what to what? Ecosystems 4(8):765-781.

Carr, E. R. 2008. Between structure and agency: livelihoods and adaptation in Ghana's Central Region. Global Environmental Change 18(4):689-699. http://dx.doi.org/10.1016/j.gloenvcha.2008.06.004

Cash, D. W., W. Adger, F. Berkes, P. Garden, L. Lebel, P. Olsson, L. Pritchard, and O. Young. 2006. Scale and cross-scale dynamics: governance and information in a multilevel world. Ecology and Society 11(2):8. [online] URL: http://www.ecologyandsociety. org/vol11/iss2/art8/

Castree, N. 2004. Differential geographies: place, indigenous rights and 'local' resources. Political Geography 23(2):133-167. http://dx.doi.org/10.1016/j.polgeo.2003.09.010

Chambers, R. 1997. Whose reality counts?: putting the first last. Intermediate Technology Publications, London, UK. http://dx. doi.org/10.3362/9781780440453

Clements, F. E. 1936. Nature and structure of the climax. Journal of Ecology 24(1):252-284. http://dx.doi.org/10.2307/2256278

Cote, M., and A. J. Nightingale. 2012. Resilience thinking meets social theory: situating social change in socio-ecological systems (SES) research. Progress in Human Geography 36(4):475-489. http://dx.doi.org/10.1177/0309132511425708

Coulthard, S. 2012. Can we be both resilient and well, and what choices do people have? Incorporating agency into the resilience debate from a fisheries perspective. Ecology and Society 17(1):4. http://dx.doi.org/10.5751/ES-04483-170104

Cretney, R. 2014. Resilience for whom? Emerging critical geographies of socio-ecological resilience. Geography Compass 8 (9):627-640. http://dx.doi.org/10.1111/gec3.12154

Cumming, G. S. 2011. Spatial resilience in social-ecological systems. Springer Netherlands, Dordrecht, Netherlands. http:// dx.doi.org/10.1007/978-94-007-0307-0

Cumming, G. S., G. Barnes, S. Perz, M. Schmink, K. E. Sieving, J. Southworth, M. Binford, R. D. Holt, C. Stickler, and T. Van Holt. 2005. An exploratory framework for the empirical measurement of resilience. Ecosystems 8(8):975-987. http://dx. doi.org/10.1007/s10021-005-0129-z

Cumming, G. S., D. H. M. Cumming, and C. L. Redman. 2006. Scale mismatches in social-ecological systems: causes, consequences, and solutions. Ecology and Society 11(1):14. [online] URL: http://www.ecologyandsociety.org/vol11/iss1/ art14l

Davidson, D. J. 2010. The applicability of the concept of resilience to social systems: some sources of optimism and nagging doubts. Society \& Natural Resources 23(12):1135-1149. http://dx.doi. org/10.1080/08941921003652940

Davidson, D. J. 2013. We still have a long way to go, and a short time to get there: a response to Fikret Berkes and Helen Ross. Society \& Natural Resources 26(1):21-24. http://dx.doi. org/10.1080/08941920.2012.749758
Duit, A., V. Galaz, K. Eckerberg, and J. Ebbesson. 2010. Governance, complexity, and resilience. Global Environmental Change 20(3):363-368. http://dx.doi.org/10.1016/j.gloenvcha.2010.04.006

Dwyer, M. B., M. L. Ingalls, and I. G. Baird. 2015. The security exception: militarization and development in Laos's protected areas. GeoForum, in press. http://dx.doi.org/10.1016/j. geoforum.2015.11.002

Engle, N. L. 2011. Adaptive capacity and its assessment. Global Environmental Change 21(2):647-656. http://dx.doi.org/10.1016/ j.gloenvcha.2011.01.019

Escobar, A. 1998. Whose knowledge, whose nature? Biodiversity, conservation, and the political ecology of social movements. Journal of Political Ecology 5(1):53-82.

Escobar, A. 1999. After nature: steps to an antiessentialist political ecology. Current Anthropology 40(1):1-30. http://dx.doi. org/10.1086/515799

Evans, B., and J. Reid. 2014. Resilient life: the art of living dangerously. Polity, Cambridge, UK.

Fabinyi, M., L. Evans, and S. J. Foale. 2014. Social-ecological systems, social diversity, and power: insights from anthropology and political ecology. Ecology and Society 19(4):28. http://dx.doi. org/10.5751/ES-07029-190428

Ferguson, A., and B. Derman. 2005. Whose water? Political ecology of water reform in Zimbabwe. Pages 61-75 in S. Paulson and L. L. Gezon, editors. Political ecology across spaces, scales, and social groups. Rutgers University Press, New Brunswick, New Jersey, USA.

Flynn, T. 2007. Foucault among the geographers. Pages 59-64 in J. W. Crampton and S. Elden, editors. Space, knowledge and power: Foucault and geography. Ashgate, Aldershot, UK.

Folke, C. 2006. Resilience: the emergence of a perspective for social-ecological systems analyses. Global Environmental Change 16(3):253-267. http://dx.doi.org/10.1016/j.gloenvcha.2006.04.002

Folke, C., S. Carpenter, T. Elmqvist, L. Gunderson, C. S. Holling, and B. Walker. 2002. Resilience and sustainable development: building adaptive capacity in a world of transformations. Ambio 31(5):437-440. http://dx.doi.org/10.1579/0044-7447-31.5.437

Foucault, M. 2007. Questions on geography. Pages 173-182 in J. W. Crampton and S. Elden, editors. Space, knowledge and power: Foucault and geography. Ashgate, Aldershot, UK.

Gaillard, J. C. 2010. Vulnerability, capacity and resilience: perspectives for climate and development policy. Journal of International Development 22(2):218-232. http://dx.doi.org/10.1002/ jid. 1675

Gallopín, G. C. 2006. Linkages between vulnerability, resilience, and adaptive capacity. Global Environmental Change 16 (3):293-303. http://dx.doi.org/10.1016/j.gloenvcha.2006.02.004

Gezon, L. L., and S. Paulson. 2005. Place, power and difference: multiscale research at the dawn of the twenty-first century. Pages 17-40 in S. Paulson and L. L. Gezon, editors. Political ecology across spaces, scales, and social groups. Rutgers University Press, New Brunswick, New Jersey, USA.. 
Hajer, M., and W. Versteeg. 2005. A decade of discourse analysis of environmental politics: achievements, challenges, perspectives. Journal of Environmental Policy \& Planning 7(3):175-184. http:// dx.doi.org/10.1080/15239080500339646

Hirsch, P. D., W. M. Adams, J. P. Brosius, A. Zia, N. Bariola, and J. L. Dammert. 2011. Acknowledging conservation trade-offs and embracing complexity. Conservation Biology 25(2):259-264. http://dx.doi.org/10.1111/j.1523-1739.2010.01608.x

Holling, C. S. 1973. Resilience and stability of ecological systems. Annual Review of Ecology and Systematics 4:1-23. http://dx.doi. org/10.1146/annurev.es.04.110173.000245

Hornborg, A. 2013. Revelations of resilience: from the ideological disarmament of disaster to the revolutionary implications of $(p)$ anarchy. Resilience 1(2):116-129. http://dx.doi.org/10.1080/2169$\underline{3293.2013 .797661}$

Ingalls, M. L., and M. B. Dwyer. 2015. REDD through the lens of resilience: navigating the trade-offs. In Proceedings of XIV World Forestry Congress, Durban, South Africa, 7-11 September 2015. Food and Agriculture Organization of the United Nations, Rome, Italy. [online] URL: http://foris.fao.org/wfc2015/api/ file/55b625d90f541f9035232ea2/contents/59a04ffc-f023-4e15afcf-92cd5bdf12ba.pdf

Jax, K., and R. Ricardo. 2004. Ecological theory and values in the determination of conservation goals: examples from temperate regions of Germany, United States of America, and Chile. Revista Chilena de Historia Natural 77:349-366. http://dx. doi.org//10.4067/s0716-078x2004000200012

Kasperson, J. X., R. E. Kasperson, and B. L. Turner, II. 1996. Regions at risk: exploring environmental criticality. Environment 38(10):4-29. http://dx.doi.org/10.1080/00139157.1996.9931008

Lebel, L., J. M. Anderies, B. Campbell, C. Folke, S. HatfieldDodds, T. P. Hughes, and J. Wilson. 2006. Governance and the capacity to manage resilience in regional social-ecological systems. Marine Sciences Faculty Scholarship. Paper 52. University of Maine, Orono, Maine, USA.

Massey, D. 1999. Space/time, 'science' and the relationship between physical geography and human geography. Transactions of the Institute of British Geographers 24(3):261-276. http://dx. doi.org/10.1111/j.0020-2754.1999.00261.x

Miller, F., H. Osbahr, E. Boyd, F. Thomalla, S. Bharwani, G. Ziervogel, B. Walker, J. Birkmann, S. Van der Leeuw, J. Rockström, J. Hinkel, T. Downing, C. Folke, and D. Nelson. 2010. Resilience and vulnerability: complementary or conflicting concepts? Ecology and Society 15(3):11. [online] URL: http:// www.ecologyandsociety.org/vol15/iss3/art11/

Nelson, D. R., W. N. Adger, and K. Brown. 2007. Adaptation to environmental change: contributions of a resilience framework. Annual Review of Environmental Resources 32:395-419. http://dx. doi.org/10.1146/annurev.energy.32.051807.090348

Okereke, C. 2006. Global environmental sustainability: intragenerational equity and conceptions of justice in multilateral environmental regimes. Geoforum 37(5):725-738. http://dx.doi. org/10.1016/j.geoforum.2005.10.005
Okereke, C., and K. Dooley. 2010. Principles of justice in proposals and policy approaches to avoid deforestation: towards a post-Kyoto climate agreement. Global Environmental Change 20 (1): 82-95. http://dx.doi.org/10.1016/j.gloenvcha.2009.08.004

Olsson, P., V. Galaz, and W. J. Boonstra. 2014. Sustainability transformations: a resilience perspective. Ecology and Society 19 (4):1. http://dx.doi.org/10.5751/ES-06799-190401

Pain, A., and S. Levine. 2012. A conceptual analysis of livelihoods and resilience: addressing the 'insecurity of agency'. HPG Working Paper. Humanitarian Policy Group, Overseas Development Institute, London, UK.

Paulson, S., L. L. Gezon, and M. Watts. 2003. Locating the political in political ecology: an introduction. Human Organization 62(3):205-217. http://dx.doi.org/10.17730/humo.62.3. e $5 \mathrm{xcj}$ d6y $8 \mathrm{v} 09 \mathrm{n} 6 \mathrm{~b}$

Paulson, S., L. L. Gezon, and M. Watts. 2005. Politics, ecologies, genealogies. Pages 17-37 in S. Paulson and L. L. Gezon, editors. Political ecology across spaces, scales and social groups. Rutgers University Press, New Brunswick, New Jersey, USA.

Peluso, N. L., and C. Lund. 2011. New frontiers of land control: introduction. Journal of Peasant Studies 38(4):667-681. http://dx. doi.org/10.1080/03066150.2011.607692

Peterson, G. 2000. Political ecology and ecological resilience: an integration of human and ecological dynamics. Ecological Economics 35:323-336. http://dx.doi.org/10.1016/S0921-8009(00) $\underline{00217-2}$

Plummer, R., and D. Armitage. 2007. A resilience-based framework for evaluating adaptive co-management: linking ecology, economics and society in a complex world. Ecological Economics 61(1):62-74. http://dx.doi.org/10.1016/j.ecolecon.2006.09.025

Sayre, N. F. 2005. Ecological and geographical scale: parallels and potential for integration. Progress in Human Geography 29 (3):276-290. http://dx.doi.org/10.1191/0309132505ph546oa

Sayre, N. F. 2008. The genesis, history, and limits of carrying capacity. Annals of the Association of American Geographers 98 (1):120-134. http://dx.doi.org/10.1080/00045600701734356

Stott, P. A., and S. Sullivan. 2000. Political ecology: science, myth and power. Arnold, London, UK.

Turner, M. D. 2014. Political ecology I. An alliance with resilience? Progress in Human Geography 38(4):616-623. http://dx.doi. org/10.1177/0309132513502770

Vayda, A. P., and B. B. Walters. 1999. Against political ecology. Human Ecology 27(1):167-179. http://dx.doi.org/10.1023/ A:1018713502547

Walker, P. A. 2005. Political ecology: where is the ecology? Progress in Human Geography 29(1):73-82. http://dx.doi. org/10.1191/0309132505ph530pr

Walker, P. A. 2006. Political ecology: where is the policy? Progress in Human Geography 30(3):382. http://dx.doi.org/10.1191/0309132506ph613pr

Walsh-Dilley, M., W. Wolford, and J. McCarthy. 2013. Rights for resilience: bringing power, rights and agency into the resilience framework. Oxfam America, Washington, D.C., USA. 
Watts, M. 2009. Political ecology. Pages 545-546 in D. Gregory, R. Johnston, G. Pratt, M. Watts, and S. Whatmore, editors. The dictionary of human geography. John Wiley \& Sons, West Sussex, UK.

Welsh, M. 2014. Resilience and responsibility: governing uncertainty in a complex world. Geographical Journal 180 (1):15-26. http://dx.doi.org/10.1111/geoj.12012

Wolf, S. A. 2011. Network governance as adaptive institutional response: the case of multifunctional forested landscapes. Journal of Natural Resources Policy Research 3(3):223-235. http://dx.doi. org/10.1080/19390459.2011.591760

Wolf, S. A., and T. F. H. Allen. 1995. Recasting alternative agriculture as a management model: the value of adept scaling. Ecological Economics 12(1):5-12. http://dx.doi.org/10.1016/0921-8009 (94)00016-O

Xu, J., L. Lebel, and J. Sturgeon. 2009. Functional links between biodiversity, livelihoods and culture in a Hani swidden landscape in Southwest China. Ecology and Society 14(2):20. [online] URL: http://www.ecologyandsociety.org/vol14/iss2/art20/

Zimmerer, K. S. 2006. Cultural ecology: at the interface with political ecology-the new geographies of environmental conservation and globalization. Progress in Human Geography30 (1):63-78. http://dx.doi.org/10.1191/0309132506ph591pr

Zimmerer, K. S. 2007. Cultural ecology (and political ecology) in the 'environmental borderlands': exploring the expanded connectivities within geography. Progress in Human Geography 31(2):227-244. http://dx.doi.org/10.1177/0309132507075372 